\title{
Eight Years of Severe Allergic Reactions in Finland A Register-Based Report
}

\author{
Soili Mäkinen-Kiljunen and Tari Haahtela
}

\begin{abstract}
Background: No data have been available on severe allergic reactions in Finland.

Materials and Methods: We summarize the data accumulated from 2000 to 2007 in the national register established at the Skin and Allergy Hospital of the Helsinki University Central Hospital, where physicians voluntarily report on patients with severe allergic reactions. Results: During the period, the 530 reported cases of severe allergic reactions represented an annual frequency of $0.001 \%$. Of the patients, $66 \%$ were adults and $56 \%$ were female, with a median age of 27 years. Food was the causative agent in $53 \%$ of the cases, drugs in $26 \%$, allergen preparations in $12 \%$, and insects in $8 \%$. Dermatologic symptoms were reported in $85 \%$, respiratory in $76 \%$, cardiovascular in $50 \%$, gastrointestinal in $33 \%$, and eye/nose symptoms in $18 \%$. The reaction was a life-threatening anaphylactic shock in $26 \%$ of the cases, with no deaths reported. Patients were treated with intramuscular adrenaline in $75 \%$ of the cases. Not only nuts and seeds, but also fruit and vegetables were the most important allergens for the adults. Nuts were also important allergens for children, along with milk, egg, and wheat. In addition, many "exotic" allergens were identified: patent blue, carmine dye, yeast, buckwheat, and macrogol.

Conclusions: Severe allergic reactions are underreported, but a register reflects the real-life situation and helps to identify new causative agents. It also contributes to improvements in first aid treatment practice.
\end{abstract}

Key Words: allergen preparation, anaphylaxis, drug, food, insect, register

(WAO Journal 2008;184-189)

$A^{n}$ naphylaxis is an immunoglobulin $\mathrm{E}$ ( $\mathrm{IgE})-$ or nonIgE-mediated, severe, life-threatening systemic allergic reaction, with a rapid onset and multiple organ system involvement. $^{1,2}$ Independent of the mechanism, the first aid treatment of choice is intramuscular adrenaline. Because of the risk of recurrent severe reaction, the causative allergen must be recognized and avoided when possible.

To our knowledge, nationwide anaphylaxis registers or similar organizations exist at least in Denmark, France-Belgium, Germany-Austria-Switzerland, Italy, the Netherlands, Norway, Sweden, the United Kingdom and

Received for publication April 29, 2008; accepted August 7, 2008.

From the Skin and Allergy Hospital, Helsinki University Central Hospital, Helsinki, Finland.

Reprints: Soili Mäkinen-Kiljunen, PhD, Skin and Allergy Hospital, Helsinki University Central Hospital, PO Box 160, 00029 HUS, Helsinki, Finland. E-mail: soili.makinen-kiljunen@hus.fi.

Copyright (C) 2008 by World Allergy Organization
Ireland, and also in the United States (Table 1). ${ }^{3-7}$ Maintaining a comprehensive anaphylaxis register involves several difficulties, for example, the lack of internationally accepted clinical definition of anaphylaxis has made it difficult to diagnose an anaphylactic reaction (Table 2).

No data reveal actual frequency of severe allergic reactions in Finland. The literature has reported incidence figures of 7.9 to 21 anaphylaxis cases per 100,000 personyears, ${ }^{8-10}$ along with increasing allergy prevalence and hospital admission figures during the past decade. ${ }^{11-13}$ In the United States, approximately 30,000 cases of food anaphylaxis occur annually, 150 to 200 of which are fatal. ${ }^{14}$ In the United Kingdom, the incidence of fatal reactions is one in 3 million person-years, and its National Anaphylaxis Campaign was set up in 1994 for guidance and information on allergens and allergic reactions. ${ }^{15-17}$

In 2000, the Finnish register of severe allergic reactions was established at the Skin and Allergy Hospital of the Helsinki University Central Hospital, where physiciansmostly allergologists - voluntarily report patients with severe allergic reactions independently of the causative agent. A 1-page questionnaire form is available on the Internet.

\section{MATERIALS AND METHODS}

We summarize the first 530 cases reported to the register between 2000 and 2007. Our results are based on the anonymous patient data provided by the physicians in the questionnaire form evaluated by an allergy specialist.

Any adverse reactions from vaccines that were reported to the National Public Health Institute are absent from the present article.

\section{RESULTS}

\section{Reports on Severe Allergic Reactions}

A total of 530 cases of severe allergic reactions were reported between 2000 and 2007 throughout the country, mostly (65\%) from the Helsinki capital area, which represents $25 \%$ of the entire population of 5.2 million. This represents an annual incidence of $0.001 \%$.

\section{Patients}

Of the 530 cases, 348 (66\%) were adults and $182(34 \%)$ were children younger than 16 years. Females accounted for $295(56 \%)$. Median age was 27 years; range was from 2 months to 92 years. Two peaks in age distribution were for children younger than 5 years and young adults aged 25 to 35 years.

A previously diagnosed allergy occurred in 91\%; skin disorders were present in $43 \%$, allergic rhinoconjunctivitis 
TABLE 1. Anaphylaxis Registers and Anaphylaxis

Organizations

\begin{tabular}{|c|c|c|}
\hline Country & $\begin{array}{l}\text { Register Type and } \\
\text { Contact Address }\end{array}$ & $\begin{array}{c}\text { Responsible Informant/ } \\
\text { Organization }\end{array}$ \\
\hline Several & $\begin{array}{l}\text { The Food Allergy and } \\
\text { Anaphylaxis Alliance } \\
\text { A voluntary registry for } \\
\text { peanut and tree nut } \\
\text { allergy (United States, } \\
\text { since 1997) }\end{array}$ & $\begin{array}{l}\text { Since } 1999 \text {, allergy network } \\
\text { groups from the United States, } \\
\text { United Kingdom, Canada, } \\
\text { Quebec, New Zealand, Italy, } \\
\text { Australia, and the Netherlands. }\end{array}$ \\
\hline Denmark & $\begin{array}{l}\text { Danish Anaesthesia } \\
\text { Allergy Centre }\end{array}$ & $\begin{array}{c}\text { Clinicians may refer their patients } \\
\text { to Danish Anaesthesia Allergy } \\
\text { Centre for further investigation }\end{array}$ \\
\hline Finland & $\begin{array}{l}\text { National anaphylaxis } \\
\text { register }\end{array}$ & $\begin{array}{l}\text { 1-Page anaphylaxis form to be } \\
\text { filled by physician }\end{array}$ \\
\hline \multirow[t]{2}{*}{$\begin{array}{l}\text { France } \\
\text { and } \\
\text { Belgium }\end{array}$} & $\begin{array}{l}\text { French Allergy Vigilance } \\
\text { Network (Available at: } \\
\text { www.cicbaa.org) }\end{array}$ & $\begin{array}{l}\text { 1-Page declaration of severe } \\
\text { allergic accident to be filled in } \\
\text { mainly by French and Belgian } \\
\text { allergists }\end{array}$ \\
\hline & $\begin{array}{l}\text { The Study Group on } \\
\text { Anaphylaxis during } \\
\text { Anaesthesia (GERAP) }\end{array}$ & \\
\hline $\begin{array}{l}\text { Germany, } \\
\text { Austria, } \\
\text { and } \\
\text { Switzerland }\end{array}$ & $\begin{array}{l}\text { Deutscher Allergie-und } \\
\text { Asthmabund } \\
\text { (Available at: } \\
\text { www.anaphylaxie.net) }\end{array}$ & $\begin{array}{l}\text { Patient organization reports from } \\
\text { clinicians }\end{array}$ \\
\hline Norway & $\begin{array}{l}\text { The Norwegian National } \\
\text { Reporting System and } \\
\text { Register of Severe } \\
\text { Allergic Reactions to } \\
\text { Food (Food Allergy } \\
\text { Register) }\end{array}$ & $\begin{array}{l}\text { Government-funded system, } \\
\text { 1-page reporting form from } \\
\text { physicians, IgE and allergen } \\
\text { analysis service }\end{array}$ \\
\hline Sweden & $\begin{array}{l}\text { Swedish system for } \\
\text { reporting severe and } \\
\text { fatal reactions caused } \\
\text { by food }\end{array}$ & $\begin{array}{l}\text { National system for reporting by } \\
\text { the medical profession }\end{array}$ \\
\hline $\begin{array}{l}\text { United } \\
\text { Kingdom }\end{array}$ & $\begin{array}{l}\text { The United Kingdom } \\
\text { anaphylaxis register }\end{array}$ & $\begin{array}{l}\text { Since } 1992 \text { for fatal anaphylactic } \\
\text { reactions in the United } \\
\text { Kingdom }\end{array}$ \\
\hline
\end{tabular}

in $43 \%$, asthma in $33 \%$, and gastrointestinal disorders in $6 \%$. A previous anaphylaxis affected $23 \%$.

The reactions were regarded as severe anaphylactic shock reactions in $26 \%$ of the cases, with a systolic blood pressure in adults less than $90 \mathrm{~mm} \mathrm{Hg}$ or with severe respiratory symptoms such as bronchospasm and upper airway angioedema. ${ }^{18}$ Other severe allergic reactions included nonshock reactions with symptoms in at least two of the following organs: skin, respiratory tract, cardiovascular system, or gastrointestinal tract. ${ }^{18}$

\section{Symptoms and Treatment}

In $74 \%$ of the cases, the first symptoms predicting severe allergic reaction appeared less than 30 minutes after contact with the inciting allergen.

Skin symptoms were most commonly reported, in $85 \%$, followed by respiratory $(76 \%)$, cardiovascular $(50 \%)$, and gastrointestinal (33\%) symptoms.

Most frequently, corticosteroids were used for treatment, in $84 \%$, followed by adrenaline in $75 \%$, and antihistamine in $67 \%$. Of the adrenaline-treated patients, $10 \%$ used a readyto-use adrenaline autoinjector.

\section{Allergens and Exposure}

Foods were the causative agent in $279(53 \%)$ cases, drugs and medical interventions in 136 (26\%), allergen preparations for diagnostic work and immunotherapy in 64 $(12 \%)$, and insects in $40(8 \%)$ (Fig. 1). In 13 patients $(2 \%)$, other causes were noted, and only 6 cases $(1 \%)$ were idiopathic or without any recognizable cause (Table 3 ). In 7 cases, both food and a drug were suspect causative agents. An additional known or suspected factor in 29 cases $(5 \%)$ was exercise.

Hospitals and other health care settings were the most common venues for severe allergic reactions overall $(33 \%)$, followed by the home (30\%), hobbies $(14 \%)$, restaurants $(7 \%)$, day care/schools $(7 \%)$, and work places $(6 \%)$.

\section{Food}

Food $(n=279)$ was the most common cause of severe allergic reaction $(53 \%)$. Of these patients, $53 \%$ were adults, $64 \%$ of whom were females, but most $(60 \%)$ of the children were boys. The home was the most common place for food reaction $(36 \%)$.

Food was responsible for $72 \%$ of the reactions in children, but for only $43 \%$ in adults. An association with exercise was documented in $8 \%$ with food-related reactions. Food caused $46 \%$ of the most severe shock reactions, including peanut/tree nuts/seeds $(\mathrm{n}=17)$, grains $(\mathrm{n}=11)$, milk $(\mathrm{n}=10)$, fruit/vegetable $(\mathrm{n}=8)$, egg $(\mathrm{n}=6)$, fish/shellfish $(\mathrm{n}=2)$, soy, and yeast among others.

An allergen-containing food was accidentally given to 53 patients, $60 \%$ of whom were children. These included milk, wheat, egg, fish, nuts, and seeds. Most episodes (77\%) took place outside the home.

Most food-related reactions were from peanuts, tree nuts, and seeds (21\%), 36\% of which occurred in children (Table 3). One adult experienced anaphylaxis after eating home-delivered Thai food that contained soft-treated peanuts, which the patient assumed were beans. Tree nuts were

TABLE 2. Difficulties in Maintaining an Anaphylaxis Register

\begin{tabular}{|c|c|c|}
\hline Problem & Solution & Suggestion \\
\hline $\begin{array}{l}\text { 1. Lack of definition } \\
\text { of anaphylaxis: } \\
\text { anaphylactic reaction } \\
\text { vs anaphylactic } \\
\text { shock }\end{array}$ & Clinical diagnosis $^{17}$ & $\begin{array}{l}\text { Combination of } \\
\text { circulatory, } \\
\text { dermatologic, } \\
\text { respiratory, } \\
\text { gastrointestinal } \\
\text { symptoms }\end{array}$ \\
\hline $\begin{array}{l}\text { 2. Not all reactions are } \\
\text { reported }\end{array}$ & $\begin{array}{l}\text { Improvement of } \\
\text { knowledge and } \\
\text { vigilance system }\end{array}$ & FAAA Ga2len network \\
\hline $\begin{array}{l}\text { 3. Not all allergens are } \\
\text { considered }\end{array}$ & $\begin{array}{l}\text { Exchange of register } \\
\text { information }\end{array}$ & FAAA Ga2len network \\
\hline 4. Allergen not identified & $\begin{array}{c}\text { More resources, better } \\
\text { organized testing }\end{array}$ & $\begin{array}{l}\text { All anaphylaxis patients } \\
\text { should be seen by an } \\
\text { allergologist }\end{array}$ \\
\hline
\end{tabular}

FAAA indicates Food Allergy and Anaphylaxis Alliance. 


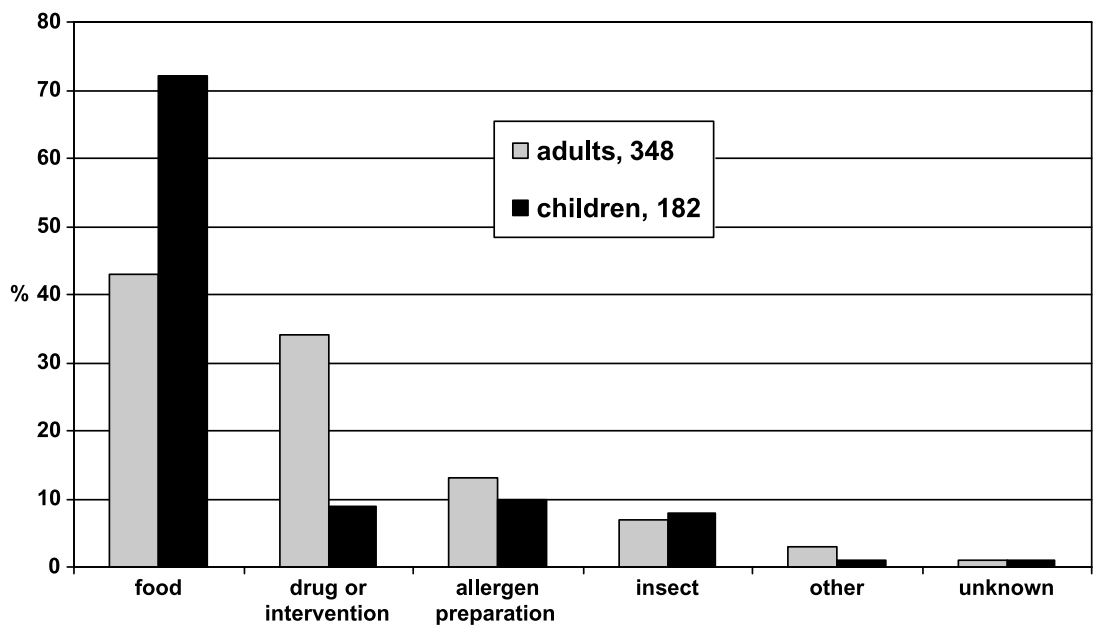

FIGURE 1. Causes for severe allergic reactions (\%) in adults and in children between 2000 and 2007 in Finland.

involved in $53 \%$ of the nut/seed cases. Hidden or nonrecognized nuts were the causative agent in bread and in ice cream. Two other patients ( 1 child and 1 adult) had anaphylaxis after eating tahini sauce not recognized by the patients as being a sesame seed product.

Fruits and vegetables were reported in $16 \%$ of the food anaphylaxis cases, of which kiwi, apple, and celery were the most common allergens. In 2 birch pollen-allergic adults, even the first ingestion of an exotic fruit such as jackfruit or lychee when abroad resulted in severe anaphylactic reactions.

Regarding grains, reports numbered $14 \%$ of the cases, $72 \%$ of which were from wheat. One wheat-allergic child had a severe reaction after eating gluten-free pasta, and another child after eating a wheat-free bun made of buckwheat to which the child had developed an allergy during a 3-year wheat-free diet. Buckwheat in a blin was unexpectedly allergenic to 1 adult patient, whereas another adult experienced anaphylaxis from a bun in which the marzipan was dyed with a red color from cochineal insects (carmine, E120).

Milk was the causative agent in $14 \%$ of the food-related anaphylaxis cases. Heavy exercise together with milk protein-containing pills caused a severe reaction in a milkallergic adult to whom the terms casein and whey were unknown. The patient had an adrenaline autoinjector, but she did not dare use it. One adult experienced anaphylaxis from cow's milk feta cheese, but she tolerated goat's milk feta, whereas another adult experienced anaphylaxis from goat cheese without a cow's milk allergy (Fig. 2).

Egg was reported in $9 \%$ of the food reactions, all but one in children, and 7 of which were accidents outside the home. In 1 case, a hidden allergen was suspected.

Fish or seafood was reported in $8 \%$ of the cases. Fish nuggets were given to a child instead of chicken nuggets (the Finnish word for fish is kala, for chicken, kana). Five reports were toxic reactions from tuna fish in which a high histamine content was suspected as the causative agent because no fish allergy was evident. Eight cases were from shrimp and one from roe in the absence of fish allergy. ${ }^{19}$

Soy was reported or suspected in 9 cases, 4 of which occurred in birch pollen-allergic patients after a soy drink. A skin prick test with native soy bean was positive, whereas a commercial serum soy-specific IgE test was negative, indicating the missing labile cross-reactive soy allergen (Gly m 4). ${ }^{20}$ In other cases, soy was suspected as a hidden allergen in the food offered in day care centers.

Yeast used as a flavoring agent in a spaghetti sauce repeatedly caused severe anaphylactic reactions in a mouldsensitive patient. $^{21}$

Drinks were reported in 11 cases (4\%), mostly (73\%) in adults. Reported drinks included red and white wine, beer, long drink, cider, juice, and glühwein. One patient repeatedly experienced anaphylaxis when dancing the tango after drinking a beer.

\section{Drugs, Allergen Preparations, and Other Interventions}

Drugs $(n=136)$, allergen preparations $(n=64)$, and other medical interventions such as food provocation tests $(\mathrm{n}=22)$ were reported in 222 cases $(42 \%)$, mostly $(75 \%)$ in adults (Table 3 ).

Antibiotics in 29\% and painkillers in 24\% were the most commonly reported in drug-related reactions. Cephalosporins and penicillins comprised 58\% of the antibiotics, whereas acetylsalicylic acid (ASA) and ibuprofen accounted for $45 \%$ of painkillers. In 4 cases, ASA in a combination product was not recognized by the patient as such.

In $68 \%$ of the operation-related reactions, a neuromuscular blocking agent (rocuronium) was suspected as the causative agent either alone or with other anesthetic agents. Three cases were caused by the patent blue dye (E 131) used to locate sentinel lymph nodes. One reaction was caused by chlorhexidine used as skin disinfectant. ${ }^{22}$ Local anesthetics were reported in 8 cases, in one of which methylprednisolone used simultaneously proved to be the anaphylactic agent based on positive intradermal testing. Nine cases were from contrast media and one from iodinated povidone (Betadine).

In a drug, the active ingredient is not always the agent causing harm. One case of penicillin anaphylaxis was caused by macrogol (polyethylene glycol) used as an excipient in the tablet vehicle. ${ }^{23}$ 
TABLE 3. Allergens Causing Severe Allergic Reactions in Finland

\begin{tabular}{|c|c|c|c|}
\hline Allergen & Adults & Children & Examples of Specific Agents \\
\hline Foods & 148 & 131 & \\
\hline Nuts/seeds & 38 & 21 & \\
\hline Tree nuts & 21 & 10 & Hazel $(\mathrm{n}=5)$, cashew $(\mathrm{n}=3)$, walnut $(\mathrm{n}=3)$, almond $(\mathrm{n}=3$; marzipan, $\mathrm{n}=1)$, pistachio $(\mathrm{n}=2)$ \\
\hline Peanut & 5 & 8 & Cooked peanut taken as beans \\
\hline Fruit & 19 & 12 & Kiwi $(n=8)$, apple $(n=5)$, banana $(n=5)$, grape $(n=3)$, mango $(n=4)$, lychee, jackfruit, plum $(n=2)$, red currant \\
\hline Milk & 7 & 31 & Cow milk $(\mathrm{n}=36)$, goat milk $(\mathrm{n}=2)$ \\
\hline Egg & 1 & 23 & \\
\hline Fish/shellfish & 14 & 9 & Tuna (high histamine; $\mathrm{n}=5$ ), perch, shrimp $(\mathrm{n}=8)$, roe \\
\hline Soy & 6 & 3 & Alpro soy drink $(n=4)$ \\
\hline Other foods & 30 & 14 & Baked roll $(n=9)$, wine $(n=3)$, carmine red $(n=2)$, sweet $(n=2)$, yeast \\
\hline Several foods & 111 & 1 & Milk-egg-wheat, a whole meal \\
\hline Penicillin & 11 & 1 & Phenoxymethyl penicillin ( $\mathrm{n}=9$ ), filling agent macrogol (polyethylene glycol) \\
\hline Other antibiotics & 12 & 2 & $\begin{array}{l}\text { Amoxicillin }(\mathrm{n}=5) \text {, macrolide }(\mathrm{n}=4) \text {, fluoroquinolone }(\mathrm{n}=2) \text {, trimethoprim }(\mathrm{n}=2) \text {, tetracycline }(\mathrm{n}=2) \text {, } \\
\text { nitrofurantoin, chloramphenicol, metronidazole }\end{array}$ \\
\hline Painkillers & 28 & 10 & \\
\hline ASA & 8 & 1 & \\
\hline Ibuprofen & 5 & 3 & Alone $(n=5)$ or with other drugs $(n=2)$ \\
\hline Paracetamol & 2 & 1 & 1 in a combination product \\
\hline Other pain killers & 11 & 2 & Diclofenac $(n=4)$, naproxen $(n=6)$, coxib $(n=3)$, mefenamic acid \\
\hline General anesthetics & 25 & 0 & \\
\hline Rocuronium & 17 & & Alone $(n=14)$ or with other anesthetics $(n=3)$ \\
\hline Patent blue & 3 & & \\
\hline Other anesthetics & 5 & & Several (antibiotic, propofol, fentanyl), gelatin \\
\hline Timothy & 32 & 13 & Alone $(n=42)$ or with birch or grass mix \\
\hline Other allergen & 5 & 4 & Birch $(n=6)$, cat $(n=2)$, dog, wasp \\
\hline SPT & 9 & 1 & Egg, fish, penicillin, mould, carmine, chironomid, several allergens \\
\hline Insects & 25 & 15 & \\
\hline Wasp & 19 & 14 & \\
\hline Other insects & 6 & 1 & Bee $(\mathrm{n}=2)$, mosquito, chironomid, unknown $(\mathrm{n}=2)$ \\
\hline Other causes & 11 & 2 & Chemical, latex, viper bite, fragrance, algae, rabbit, plant, other $(\mathrm{n}=5)$ \\
\hline Not known & 4 & 2 & \\
\hline All & 348 & 182 & In some cases, several causes were present \\
\hline
\end{tabular}

Allergen preparations were the causative agent in 64 cases $(12 \%), 18$ of which occurred in children. Ten reports with mild reactions were from skin prick testing with fish, egg, penicillin, moulds, pollens, animals, chironomid, or carmine dye (E120). Carmine IgE was positive in in-house immunospot test but remained negative in the commercial IgE test, which, however, was improved in collaboration with our laboratory.

Of all reports, $54(10 \%)$ concerned specific immunotherapy (SIT). In $83 \%$ of the reactions, timothy grass was the causative allergen, either alone or with other pollen allergens. Nine patients were on a maintenance dose; some for several years.

Of the severe anaphylactic shock reactions, $45 \%$ were caused by drugs, allergen preparations, and other interventions, such as operations $(n=16)$, painkillers $(n=13$; ASA, coxib, naproxen, ibuprofen), $\beta$-lactams $(n=11)$, timothy SIT $(n=5)$, $\mathrm{x}$-ray contrast media $(\mathrm{n}=5)$, infliximab, sodium aurothiomalate, and a natural remedy (pollen) among others. 


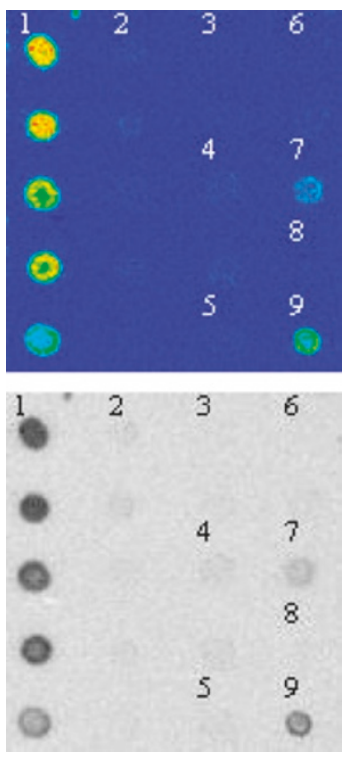

FIGURE 2. In-house immunospot method demonstrates serum IgE to the inner part of the goat cheese delivered by the patient with anaphylaxis, ${ }^{1}$ but not to cow's milk. ${ }^{8}$ Other examples are the mouldy surface of the goat cheese, ${ }^{2}$ cow milk casein, ${ }^{3}$ sheep milk casein, ${ }^{4}$ carrageen used in the cheese, ${ }^{5}$ cacao also suspected as an allergen, ${ }^{6}$ egg white, ${ }^{7}$ and goat cheese from the laboratory repertory. ${ }^{9}$

\section{Insects and Other Agents}

Insects were reported in $8 \%$ of the cases, $63 \%$ of which were in adults. Wasps (92\%) were by far the most commonly reported. Insects caused $9 \%$ of the severe shock reactions.

\section{DISCUSSION}

Based on our study, during the 8 years, 530 severe allergic reactions were reported to the Finnish register for an annual incidence of $0.001 \%$. Reactions are undoubtedly underreported, with higher figures per population reported elsewhere. $^{10}$

From the reactions, 26\% were life-threatening circulatory or respiratory shock reactions. Adrenaline was the first aid treatment for $75 \%$, but corticosteroids were more frequent: $84 \%$ of all cases. In a Swiss study, $48 \%$ of the anaphylaxis patients with circulatory symptoms received adrenaline, ${ }^{9}$ whereas in an Italian study, only $6 \%$ of the patients did. ${ }^{24}$ Finnish health care is thus reasonably well prepared to use adrenaline appropriately, but still with room for improvement.

In $5 \%$ of our cases, a late-phase reaction occurred compared with late reactions reported in $2 \%$ to $20 \%$ of cases elsewhere. $^{13,25}$

Food, drugs, and insects alternate globally as the most common causes of anaphylaxis..$^{9,11,13,18,26}$ In an overview from 1 referral clinic, $59 \%$ of the anaphylactic cases were considered idiopathic. ${ }^{27}$ In our register, food was the most commonly reported cause $(53 \%)$, and only $1 \%$ of the cases were without a known or highly suspect cause. Fruits, vegetables, nuts, and seeds were the most common causes for food reactions in adults. Similarly, fresh fruits and vegetables have been the most important allergens in adult anaphylaxis in Italy. ${ }^{24}$ Thirteen $(5 \%)$ of the food reactions involved peanut, a common cause for fatal anaphylaxis in the United States and United Kingdom, where the Anaphylaxis Campaign has also reported an increasing frequency/number of sesame anaphylaxis. ${ }^{14,28}$ Two of our patients experienced anaphylaxis from sesame sauce tahini. Fish and shellfish were rather seldom reported $(8 \%)$ but are common causes of anaphylaxis in Italy, Asia, and the United States. ${ }^{13,14,24,27}$ No deaths from food are known in Finland.

Diagnostics and other interventions are not without risks. ${ }^{8-10,13,15,28,29}$ Of our cases, $42 \%$ were from drugs, operations, diagnostics, and other interventions. In line with the reports of neuromuscular blocking agents as the most frequently implicated anesthetic drug, rocuronium was the causative agent in $68 \%$ of the surgical anaphylaxis cases. $10,29,30$

Severe allergic reactions from allergy diagnostics (skin test and food/drug challenge test) and allergy treatment (SIT) comprised $18 \%$ of the cases, and a high frequency of SIT anaphylaxis has been reported only by Mehl et al. ${ }^{26}$ Timothy pollen SIT, but not birch pollen SIT, seems to be associated with a relatively high risk for severe reactions, a fact practitioners giving SIT in Finland have been warned about.

Insects are important anaphylactic allergens in Switzerland and in the United Kingdom but account for only $8 \%$ of the reports in Finland, wasps being the most frequently reported. ${ }^{8,9}$ Because commercial skin prick and serum IgE tests are not always sufficiently sensitive and specific to identify the sensitizing insect, for SIT assessment in our hospital, an in-house immunospot method with several venom samples differentiates between wasps and honey bees. $^{21}$ No deaths were reported, although such fatalities are estimated to occur approximately every second year in Finland.

We found only 1 report on severe reaction from latex, an important allergen in France and the United States. ${ }^{10,18,25,27,30}$

To avoid is to identify. Our register has been proven to be valuable for identifying causes for severe allergic reactions in Finland. Thus far, poorly recognized allergens and allergen sources have been detected, such as patent blue, carmine, yeast, buckwheat, soy drink, and macrogol. In addition, hidden allergens have been demonstrated in food and drugs. In France, hidden allergens have accounted for $13 \%$ of severe anaphylactic reactions. ${ }^{10}$

Our register has also contributed to first aid treatment practice by highlighting the importance of intramuscular adrenaline as first-line treatment.

All patients experiencing a severe allergic reaction should be sent to an allergologist who will evaluate the causative agent, provide guidance for avoidance and prevention, and also consider SIT. The patient, family members, and caregivers must be instructed on how to use an adrenaline autoinjector.

\section{ACKNOWLEDGMENT}

This article is associated with the Finnish Allergy Programme 2008-2018 and the World Health Organization 


\section{Global Alliance against Chronic Respiratory Diseases Project.}

\section{REFERENCES}

1. Johansson SG, Hourihane JO, Bousquet J, Bruijnzeel-Koomen C, Dreborg S, Haahtela T, et al. A revised nomenclature for allergy. An EAACI position statement from the EAACI nomenclature task force. Allergy. 2001;56:813-824.

2. Simons FER. Anaphylaxis. J Allergy Clin Immunol. 2008;121: S402-S407.

3. Sicherer SH, Mundoz-Furlong A, Sampson HA. Prevalence of peanut and tree nut allergy in the United States determined by means of a random digit dial telephone survey: a 5-year follow-up study. J Allergy Clin Immunol. 2003;112:1203-1207.

4. Løvik M, Namork E, Fæste C, Egaas E. The Norwegian national reporting system and register of severe allergic reactions to food. Norsk Epidemiologi. 2004;14:155-160.

5. Foucard T, Malmheden Yman I. A study on severe food reactions in Sweden - is soy protein an underestimated cause of food anaphylaxis? Allergy. 1999;54:261-265.

6. Foucard T, Malmheden Yman I. Food-induced anaphylaxis. Pediatr Allergy Immunol. 2001;12(suppl 14):97-101.

7. Colver AF, Nevantaus H, Macdougall CF, Cant AJ. Severe food-allergic reactions in children across the UK and Ireland, 1998-2000. Acta Pædiatrica. 2005;94:689-695.

8. Peng MM, Jick H. A population-based study of the incidence, cause, and severity of anaphylaxis in the United Kingdom. Arch Intern Med. 2004;164:317-319.

9. Helbling A, Hurni T, Müller UR, Pichler WJ. Incidence of anaphylaxis with circulatory symptoms: a study over a 3-year period comprising 940 000 inhabitants of the Swiss Canton Bern. Clin Exp Allergy. 2004:34:285-290.

10. Moneret-Vautrin DA, Morisset M, Flabbee J, Beaudoin E, Kanny G. Epidemiology of life-threatening and lethal anaphylaxis: a review. Allergy. 2005;60:443-451.

11. Gupta R, Sheikh A, Strachan D, Anderson HR. Increasing hospital admissions for systemic allergic disorders in England: analysis of national admissions data. BMJ. 2003;327:1142-1143.

12. Gupta R, Sheikh A, Strachan DP, Anderson HR. Time trends in allergic disorders in the UK. Thorax. 2007;62:91-96.

13. Jirapongsananuruk $\mathrm{O}$, Bunsawansong $\mathrm{W}$, Piyaphanee $\mathrm{N}$, Visitsunthorn $\mathrm{N}$, Thongngarm T, Vichyanond P. Features of patients with anaphylaxis admitted to a university hospital. Ann Allergy Asthma Immunol 2007;98:157-162.

14. Sampson HA. Anaphylaxis and emergency treatment. Pediatrics. 2003;111:1601-1608
15. Pumphrey R. Anaphylaxis: can we tell who is at risk of the fatal reaction? Curr Opin Allergy Clin Immunol. 2004;4:285-290.

16. Pumphrey RSH. Lessons for management of anaphylaxis from a study of fatal reactions. Clin Exp Allergy. 2000;30:1144-1150.

17. Uguz A, Lack G, Pumphrey R, Ewan P, Warner J, Dick J, et al. Allergic reactions in the community: a questionnaire survey of members of the anaphylaxis campaign. Clin Exp Allergy. 2005;35:746-750.

18. Sampson HA, Munoz-Furlong A, Campbell RL, Adkinson AN Jr, Bock SA, Brown SGA, et al. Second symposium on the definition and management of anaphylaxis: summary report-Second National Institute of Allergy and Infectious Disease/Food Allergy and Anaphylaxis Network symposium. J Allergy Clin Immunol. 2006;117:391-397.

19. Mäkinen-Kiljunen S, Kiistala R, Varjonen E. Severe reactions from roe without concomitant fish allergy. Ann Allergy Asthma Immunol. 2003;91:413-416.

20. Süss A, Rytter M, Sticherling M, Simon JC. Anaphylaktische Reaktion auf ein Sojagetränk bei drei Patienten mit Birkenpollenallergie. JDDG. 2005;3:895-897.

21. Airola K, Petman L, Mäkinen-Kiljunen S. Clustered sensitivity to fungi: anaphylactic reactions caused by ingestive allergy to yeasts. Ann Allergy Asthma Immunol. 2006;97:294-297.

22. Aalto-Korte K, Mäkinen-Kiljunen S. Symptoms of immediate chlorhexidine hypersensitivity in patients with a positive prick test. Contact Dermatitis. 2006;55:173-177.

23. Hyry H, Vuorio E, Varjonen E, Skyttä J, Mäkinen-Kiljunen S. Two cases of anaphylaxis to macrogol 600 after ingestion of drug tablets. Allergy. 2006;61:1021.

24. Pastorello EA, Rivolta F, Bianchi M, Mauro M, Pravettoni V. Incidence of anaphylaxis in the emergency department of a general hospital in Milan. J Chrom B. 2001;756:11-17.

25. Ellis AK, Day JH. Incidence and characteristics of biphasic anaphylaxis: a prospective evaluation of 103 patients. Ann Allergy Asthma Immunol. 2007;98:64-69.

26. Mehl A, Wahn Y, Niggemann B. Anaphylactic reactions in children-a questionnaire-based survey in Germany. Allergy. 2005;60:1440-1445.

27. Webb LM, Liebermann P. Anaphylaxis: a review of 601 cases. Ann Allergy Asthma Immunol. 2006;97:39-43.

28. Derby CJ, Gowland MH, Hourihane JOB. Sesame allergy in Britain: a questionnaire survey of members of the Anaphylaxis Campaign. Pediatr Allergy Immunol. 2005;16:171-175.

29. Thong BY-H, Chan Y, . Anaphylaxis during surgical and interventional procedures. Ann Allergy Asthma Immunol. 2004;92:619-628.

30. Karila C, Brunet-Langot D, Labbez F, Jacqmarcq O, Ponvert C, Paupe J, et al. Anaphylaxis during anesthesia: results of a 12 -year survey at a French pediatric center. Allergy. $2005 ; 60: 828-834$. 